\title{
Legal Aspects of the Use of "Ordinary Simple Interest"
}

The division of the Gregorian calendar into months of unequal length complicates the calculation of periodic interest. Computation of payments on the basis of an equal daily rate causes the charge per month to vary. On the other hand, if equal monthly charges are maintained, the daily rate of interest must vary.

This choice between equal daily and equal monthly charges has resulted in the common use of two systems of interest calculation. The 365/365 method calculates interest payments on the basis of equal daily charges; the nominal annual rate is divided by 365 and the resulting daily rate is multiplied by the amount of the outstanding principal and the actual number of days in the payment period. ${ }^{1}$ In contrast, the $360 / 360$ method is designed to yield equal monthly payments regardless of variances in the number of days in the payment period. Under this method, interest payments are computed either by dividing the nominal annual rate by twelve and multiplying by the amount of the outstanding principal and the number of months the payment covers or by dividing the annual rate by 360 and multiplying by the number of days in the payment period; in either case, the $360 / 360$ method treats all months as having thirty days. Both the $365 / 365$ and the $360 / 360$ methods produce "exact simple interest" -neither distorts the nominal interest rate. ${ }^{2}$ If the nominal rate accurately reflects the agreement of the parties and complies with any applicable usury law, no legal problem results from the use of either method.

There is, however, a third method of interest calculation in general use, the $365 / 360$ method. This hybrid of the two techniques described above results in a substantial distortion of the nominal interest rate, particularly when it is used to compute interest for extended payment periods. Under this method, interest payments are computed by first dividing the nominal annual rate by 360 and then multiplying the result by the amount of the outstanding principal and the actual number of days in the payment period. This method, like the $365 / 365$ method, produces equal daily interest charges, but since it employs a

1 The existence of leap years does not affect the analysis and will be ignored.

2 Both methods are referred to by courts as computed on a 365 day year. See Silverstein v. Shadow Lawn Sav. \& Loan Ass'n, 51 N.J. 30, 237 A.2d 474 (1968). 
fictional 360 day year the daily charge is somewhat higher than that produced by the $365 / 365$ method. In effect, the $365 / 360$ method assesses the nominal annual rate of interest every 360 days; over a full year the nominal rate is thus increased by $1 / 72 .^{3}$

The banking industry's use of this "ordinary simple interest"4 computation has resulted in a great distortion in aggregate interest charges. A Federal Reserve Board study indicates that, in 1971, 82 percent of all commercial banks used ordinary simple interest to calculate interest on at least some loans; ${ }^{5}$ in addition, banks that have adopted the $360 / 360$ method for long-term calculations typically use the $365 / 360$ method to compute charges for days beyond the end of a month. ${ }^{8}$ Congressman Wright Patman has estimated that of the total amount of interest collected annually in the United States $\$ 145$ million is due to the difference between stated and actual rates that results from use of the $365 / 360$ method. ${ }^{7}$

In the past two years class actions challenging the legality of the $365 / 360$ method have been filed against lenders in nine states. ${ }^{8}$ About half of the suits allege that it is usurious to set the nominal rate of interest at the maximum lawful rate and then to compute payments by the $365 / 360$ method, since the computation yields an effective interest rate above the statutory maximum. The others allege that it is a breach of contract to compute interest payments by the $365 / 360$ method, since the nominal rate of interest stated in the contract is less than the rate actually charged. The total potential liability in

3 For periods of less than one year the magnitude of the effect of the $365 / 360$ method depends upon the length of the period and the time of the year. For example, compared to the $360 / 360$ method, the $365 / 360$ method has more effect on interest calculations from July 10 to January 10 than on calculations for the period from January 10 to July 10. See note 17 infra.

4 This method is also referred to as computation on a 360 day year. See Silverstein v. Shadow Lawn Sav. \& Loan Ass'n, 51 N.J. 30, 237 A.2d 474 (1968).

5117 Cong. Rec. H $4834-41$ (daily ed. June 7, 1971). Some banks do not use the method for all loans, but a significant number of banks use ordinary simple interest in each category of loans covered by the survey. For example, the method is used by 46 percent of the banks for personal loans with maturities exceeding one year, by 53 percent of the banks for commercial loans longer than one year, and by 55 percent for residential mortgages.

- See Brief for American Bankers Association as amicus curiae at 19, American Timber \& Trading Co. v. First Nat'l Bank, 334 F. Supp. 888 (D. Ore. 1971) [hereinafter cited as Bankers Association Brief].

7117 Cong. Rec. H 4834 (daily ed. June 7, 1971). This estimate ignores the fact that lenders may, in the future, simply state a higher nominal rate if exact simple interest must be used. That possibility, however, is irrelevant to a calculation of the potential recovery in cases where banks have calculated interest by the 365/360 method.

8 The states are Arizona, Galifornia, Illinois, Indiana, Minnesota, New York, Oregon, Pennsylvania, and Washington. 
these suits is substantially greater than the amount mentioned by Congressman Patman. The applicable state statutes of limitations typically allow plaintiffs to recover for more than one year's excess interest in the latter cases, and state usury penalties exceed the additional interest attributable to the choice of method of calculation. ${ }^{2}$ The prospect of such substantial liability has caused great concern within the banking industry. ${ }^{10}$

\section{Historical Background of the Use of the 365/360 Method}

The 365/360 method has been the standard method of interest calculation in the banking industry for the last two centuries.11 The first American bank, the Bank of North America in Philadelphia, limited the maturities of notes to sixty days in order to avoid risk.12 The bank, and other banks following it, treated the sixty days as onesixth of a year, justifying this procedure as a reasonable way to avoid the computational difficulties that greater precision would have required.13 Sixty day obligations were typically renewed, with the result that the inexact computation was applied for periods of a year or more; borrowers paid a full year's interest for six successive sixty day periods or 360 days. The effect of this technique increasing the effective rate of interest was extended in later years by the banks' conversion of longer loan periods into terms of days, computing interest by means of the $365 / 360$ method. ${ }^{14}$

The argument advanced to justify adoption of the $365 / 360$ method, that it was a more convenient computation than the available alternatives, is unconvincing. First, it would have been at least as easy to state the maturities of notes in terms of months rather than days and then to compute interest by the $360 / 360$ method, thus obtaining exact simple interest. ${ }^{15}$ Second, almost all banks used Rowlett's Tables ${ }^{16}$

O See note 53 infra.

10 Bankers Association Brief, supra note 6, at 5.

11 R. Kester, Accounting Theory and Practice 197 (2d ed. 1924); M. Meyer \& J. MaDaniel, Don't Bank ON IT! 109, 164 (1970); J. Webi, A Treatise on the LAW of UsuRY 153 (1899). Older authorities are discussed in Bankers Association Brief, supra note 6 , at 12-22; cf. note 47 infra.

12 J. Rowlet, Rowlett's Tables of Discount, or INTERest 9 (5th ed. 1836) [hereinafter cited as RowLetr's TABLES].

13 Id. at 9. Manual calculation for the $365 / 365$ method is more difficult than for the $365 / 360$ method. The daily rate when the $365 / 365$ basis is applied to a 12 percent nominal annual rate is .0003287671 ; when the $365 / 360$ basis is used the daily rate is .0003333333 .

14 RowletT's TABLES, supra note 12 , at 9.

15 Some distortion would still occur where the $365 / 360$ method was used to compute interest for days beyond the end of a month, but this would be of a much smaller magnitude than that produced by long-term application of the $365 / 360$ method.

16 The tables are organized by dollar amounts; for each amount up to $\$ 10,000$ interest 
to compute interest, and the Tables were not designed to yield interest readily on the $365 / 360$ basis. ${ }^{17}$ It seems likely, therefore, that the custom of using the $365 / 360$ method was motivated, at least in part, by a desire to increase interest receipts.

\section{THE USURY IsSUE}

In spite of the unconvincing rationale for use of the $365 / 360$ method and the substantial interest over-charges produced by its application, there has been little legislative reaction to the practice. Almost all state usury statutes are silent as to the effect they may have on the method of calculating interest. State legislatures that have dealt with the subject have generally validated the banking industry's use of the $365 / 360$ method. ${ }^{18}$ Only Montana requires that interest

at 6 percent is given for periods of days up to sixty-four, months from three to twelve, and for eighteen and twenty-four months.

17 Rowlett calculated the amounts for periods of days in his tables by the $365 / 360$ method and the amounts for periods of months by the $360 / 360$ method. However, when a bank clerk wanted to calculate interest from July 10 to January 10 , he would not look at the six months' figure in the table. That would yield what Rowlett calls "Statute or Lawful Interest," applicable to judgments and the like. Rowlert's TABLEs, supra note 12 , at 11. He distinguishes between this amount and "Bank Interest" which is used to calculate interest on obligations to banks. According to Rowlett's directions the term of the loan is first converted into days, and then into months and days treating thirty days as one month. The amount of the interest charge is then obtained by adding the interest figures for the corresponding number of months and days.

18 In response to the New York cases discussed below, the Connecticut and Maryland legislatures in 1827 prohibited borrowers from charging that calculating interest according to Rowletr's TABLES converted an otherwise lawful rate to a usurious one. PUB. Laws Conn. ch. 26, § 2 (1827); Pub. LAws MD. ch. 99, § 2 (1827); cf. Savings Bank v. Bates, 8 Conn. 505 (1831); Duvall v. Farmers Bank, 7 Gill \& J. 44 (Md. 1835). Maryland has since amended its statute to limit the use of the 365/360 method to periods of less than one year, while the method is still valid without limitation in Connecticut. ConN. Gen. Stat. ANN. § 37-1(a) (Supp. 1973); MD. ANN. Code art. 49, § 4 (1957). South Dakota and New Jersey have provisions that are substantially identical to the Maryland statute. N.J. Rev. Stat. § 31:1-1(a) (Supp. 1972); S.D. Compiled LAws ANn. § 54-3-4 (1967). Minnesota provides that charging one-twelfth of 8 percent for thirty days does not violate the 8 percent usury ceiling. MrNN. STAT. $\$ 334.03$ (1966). Arkansas ambiguously provides that, in computing interest, a month is one-twelfth of a year and consists of thirty days. ARR. Star. ANN. \$ 68-605 (1947). This provision could be read to validate the $365 / 360$ method or to approve the $360 / 360$ method and the $365 / 360$ method for parts of a month.

A Congressional Committee inquired into whether the Second Bank of the United States was "in the practice of taking more than six percent" interest. RowLETr's TABLES, supra note 12, at 1, quoting H.R. REP. No. 59, 17th Cong., 1st Sess. (1822). The Committee found that the bank charged I percent interest for sixty days, thus collecting more than 6 percent for 365 days. This practice, said the Committee conformed to "universal usage in the United States . . a and to the most approved tables heretofore in use." Id. (emphasis in original). The recommendation to the House of Representatives was that there was no need for corrective legislation. Later, Congress declared that it was lawful for all District of Columbia banks to compute interest according to Rowlett's Tables. Act of May 24, 1828, ch. 115, 4 Stat. 310. 
computations be based on a 365 day year for the purpose of the state usury law. ${ }^{19}$ If state legislatures have been aware of the inflated interest produced by the $365 / 360$ calculations, traditional methods of statutory construction might infer approval from their inaction.

\section{A. Arguments from Convenience}

The initial reaction in the courts to the practice of charging the maximum interest rate allowed by law, and then computing interest by means of the 365/360 method, was not so favorable. In New York Firemen Insurance Co. v. Ely \& Parsons, ${ }^{20}$ the earliest reported case on this question, the lender admitted knowing that the 365/360 method increased the actual yield to more than the stated statutory maximum. The court refused to accept as a defense the lender's good faith belief in the legality of the method; it held that in this case, as in other cases involving mistakes of law, "ignorance or mistake . . . can afford no protection." 21 The court also rejected the defense that the plaintiffs' method of calculation was generally accepted in the trade. ${ }^{22}$ It concluded that the legal quarter of a year is ninety-one days, and that, therefore, despite the small amount of additional interest involved, ${ }^{23}$ it was usurious to apply one-fourth of the nominal annual rate to a ninety day note. ${ }^{24}$

Throughout the remainder of the nineteenth century, however, the position taken in Ely was uniformly rejected.25 The courts apparently

19 Mont. Rev. Code ANN. $\S 47-124$ (Supp. 1971). This statute originally allowed computations based on a 360 day year, but was amended in 1899, possibly reflecting a rejection of whatever validity the rationale behind the use of the 365/360 method had seventy years earlier. MoNr. CIv. CoDE § 2585 (1895); GEN. LAws MONT. 125 (1899).

202 Cow. 678 (N.Y. 1824). The plaintiffs were suing to collect a ninety day note that had been discounted at 7 percent, the statutory maximum. Plaintiffs' clerk testified that he computed the interest by treating ninety days as one-fourth of a year. The facts of all usury cases are substantially the same.

212 Cow. at 705. A lower court later held that a lender in a similar position had not committed usury where the parties agreed that the lender did not know that the practice increased the annual yield. Utica Ins. Co. v. Kip, 3 Wend. 369 (N.Y. Sup. Ct. 1829).

222 Cow. at 707.

232 Cow. at 707. In another case, the court explicitly refused to apply the maxim de minimis non curat lex and based a holding of usury on Ely. Bank of Utica v. Wager, 2 Cow. 712 (N.Y. 1824).

24 The court asserted that "a different mode of calculating interest on notes payable at 60 or 90 days, and notes payable in 2 or 3 months, is established and practiced." 2 Cow. at 707. This statement is unsound. The court apparently attaches some weight to the fact that the statement would be true in England. See J. Chrtr, A Practical TreaTISE ON BULIS of Exchange 698-701 (5th ed. 1818). The assertion is erroneous as applied to American banks; in this country the banks converted the terms of loans into days and calculated interest by the 365/360 method. See text and notes at notes 11-17 supra.

25 See Bradley v. McKee, 3 F. Cas. 1156 (No. 1784) (C.C.D.C. 1837); Planters Bank v. Bass, 2 La. Ann. 430 (1847); Agricultural Bank v. Bissell, 29 Mass. (12 Pick.) 586 (1832); 
were reluctant to hold loans usurious solely because of the small computational inaccuracy produced by traditional bank methods. Instead, they looked to whether the lender had had a specific intent to violate the usury statute. ${ }^{26}$ This focus effectively condoned the calculation of interest by the $365 / 360$ method. The earliest such case was Agricultural Bank v. Bissell, ${ }^{27}$ in which the court acknowledged that the method was inaccurate, but expressed concern about the difficulties that a judicial requirement of strict accuracy would create. The court accepted the $365 / 360$ method as necessary for computational simplicity and, noting the long standing use of the method, declined to infer a usurious intent "from the mere fact that the interest thus computed slightly exceeds the legal rate."28

Other courts generally followed the rationale of Bissell. Having read a specific intent requirement into the usury statutes, they apparently regarded the taking of interest in excess of the legal limit as merely evidence from which such intent might be inferred. ${ }^{29}$ This afforded the lenders a simple defense-that established custom and the need for easy calculation justified the use of the $365 / 360$ method. Like Bissell, the subsequent cases reflect complete acceptance of the claim that "the only object was convenience and accuracy, and that the sordid motive of avarice which controls and influences the usurer, had no share in the transaction." 30

The results in these cases are questionable for several reasons. First, none of the usury statutes includes, on its face, a requirement of specific intent. ${ }^{21}$ Second, assuming that specific intent is required, it is

Planters Bank v. Snodgrass, 5 Miss. (4 How.) 573 (1840); Lafayette Bank v. Findlay, 1 Ohio Dec. Reprint 49 (1844); Pool v. White, 175 Pa. 459 (1896); Parker v. Cousins, 43 Va. (2 Gratt.) 372 (1845); State Bank v. Cowan, 35 Va. (8 Leigh) 238 (1837). Contra, Haas v. Flint, 8 Blackf. 67 (Ind. 1846).

26 These courts read the usury law in the same manner as criminal statutes for which some intent other than the intent to do the act is required for guilt. See, e.g., People v. Brown, 105 Cal. 66, 38 P. 518 (1894) (larceny); Simpson v. State, 81 Fla. 292, 87 So. 920 (1921) (burglary); Posey v. State, 22 Ga. App. 97, 95 S.E. 325 (1918) (assault with intent to commit burglary); Merritt v. Commonwealth, 164 Va. 653, 180 S.E. 395 (1935) (criminal attempt).

2729 Mass. (12 Pick.) 586 (1832). An earlier case involved the question whether charging one-fourth of the nominal annual rate for a ninety day note violated a bank charter. The court never addressed itself to the question, but allowed the lender to recover on the note. Lyon v. State Bank, 1 Stew. 442 (Ala. 1828).

2829 Mass. (12 Pick.) at 589.

29 Planters Bank v. Snodgrass, 5 Miss. (4 How.) 573 (1840). The court rejected the New York view that "receiving interest intentionally is sufficient evidence of a corrupt agreement." Bank of Utica v. Wager, 2 Cow. 712, 769 (N.Y. 1824).

305 Miss. (4 How.) at 626.

31 Illinois is typical in providing only that where "any person -or corporation knowingly contracts for or receives, directly or indirectly ... unlawful interest," the debtor 
difficult to accept the courts' conclusions in these cases that no such intent had been made out. The invocation of custom and ease of calculation indicates only that lenders thought it in their own self-interest - because less expensive-to use the $365 / 360$ method. The convenience defense thus amounts to little more than saying that the taking of interest in excess of the usury limit is justified by its profitability to lenders. Third, the courts of this era failed to understand that use of tables yielding exact simple interest might have been even more convenient or desirable. ${ }^{32}$ Instead, when faced with this claim, courts dismissed the problem as unimportant, since each borrower suffers only slight harm in relation to the size of his debt. ${ }^{33}$ It is, of course, true that the excess interest due to the $365 / 360$ method in each individual case is relatively small; nonetheless, the impact of the practice on the economy as a whole should not be ignored. ${ }^{34}$

It is generally agreed that usurious intent will be inferred if unlawful interest is intentionally taken. ${ }^{35}$ Although a mechanical error in calculation will negate usurious intent, ${ }^{36}$ a mistake with respect to the legal right to collect a particular sum will not. ${ }^{37}$ This rule of law places on lenders the burden of keeping themselves within the law, ${ }^{38}$ an appropriate burden under statutes that are intended to protect borrowers. It is incongruous that a majority of courts in this century, as in the last, have generally applied a different rule when faced with usury cases involving use of the $365 / 360$ method. This rule, as one court has stated it, is that "where several methods of computation may be used in arriving at the interest, and one is used which by strict construction would result in more than the legal rate, but with the

may recover an amount equal to twice the total interest charge. IlL. REv. STAT. ch. 74, $\S 6$ (1972).

32 See text and notes at notes 16-17 supra.

33 The excess interest received by the lender is far less than that received by taking a year's interest in advance, a practice which had received general judicial approval. $C f$. Fleckner v. Bank of United States, 8 Wheat. (21 U.S.) 338 (1923); N.Y. Firemen Ins. Co. v. Ely \& Parsons, 2 Cow. 678 (N.X. 1824).

34 See text at note 7 supra. See also Bank of Utica v. Wager, 2 Cow. 712, 763 (N.Y. 1824).

35 See, e.g., DeKorwin v. First Nat'l Bank, 275 F.2d 755, 762 (7th Cir.), cert. denied, 364 U.S. 824 (1960); National Equip. Rental v. Stanley, 177 F. Supp. 583, 586 (E.D.N.X. 1959), aff'd, 283 F.2d 600 (2d Cir. 1960); Slaughter v. First Nat'l Bank, 109 Ala. 157, 19 So. 430 (1896); 91 C.J.S. Usury \& 14, at 585 n.60 (1955).

36 See, e.g., Gilliam v. Peebles, 144 Ark. 573, 223 S.W. 14 (1920); Livingston v. Bird, 1 Root 303 (Conn. 1791); Utica Ins. Co. v. Kip, 3 Wend. 369 (N.Y. Sup. Ct. 1829); Annot., 11 A.L.R.3d 1498, 1502-07.

37 See, e.g., Brooks v. Burgess, 228 Ark. 150, 306 S.W.2d 104 (1957); Jefferson Standard Life Ins. Co. v. Davis, 173 Miss. 854, 859, 163 So. 506, 507 (1935).

38 Brooks v. Burgess, 228 Ark. 150, 153, 306 S.W.2d 104 (1957); cf. American Timber \& Trading Co. v. First Nat'l Bank, 334 F. Supp. 888 (D. Ore. 1971). 
intention only of expediting the computation or following a convenient business practice, the contract will not be held usurious." 39

It is doubtful that this rule, however justifiable it may once have been, is warranted today. ${ }^{40}$ There have been several changes in circumstances that should lead to the rejection of the earlier cases. First, the convenience rationale loses its viability when the maturities of loans are extended beyond one year; ${ }^{41}$ if anything, the $365 / 360$ method complicates calculations for terms of a year or longer. Second, Rowlett's Tables is no longer a commercial necessity. Interest is now calculated, not by uneducated bank clerks, but by computers that can easily be programmed to use any method of calculation. The advanced technology would seem to support an inference that the lender using the $365 / 360$ method does so in order to collect the excess interest rather than to promote convenience. A strict application of the specific intent analysis today might well preclude lenders from using the method. It is reasonably clear that only the courts' past approval of the method would now prevent a finding of intent to violate the usury law.

The most recent case on the question, American Timber \& Trading Co. $v$. First National Bank, ${ }^{42}$ indicates that the nineteenth century rationale will be carefully reexamined. The court in American Timber rejected the custom and convenience rationale, stating that usury legislation "should be construed with regard to its net effect upon the borrower rather than upon the bookkeeping burden, customs, or convenience of the lender." 43 Thus focusing on the harm to the borrower,

39 Cotton v. Commonwealth Loan Co., 206 Ind. 626, 633, 190 N.E. 853, 856 (1934). The same rationale led the courts to accept the taking of interest in advance. See note 33 supra.

40 In fact not all courts were wholeheartedly enthusiastic about this judicial creativity. One judge noted that he had always felt that the practice was usurious; his opinion was strengthened by the New York cases. However, he accepted a holding that the practice was not usurious due to "general judicial acquiescence." State Bank v. Cowan, 35 Va. (8 Leigh) 238, 253 (1837). Another writer in the same case, after praising the innovation of interest tables to ease calculation, expressed his disappointment that the tables were based on the "false postulate" that the year contained only 360 days. Id. at 257. Despite this disapproval, this writer concluded that the practice was not usurious because of the small amount of the excess interest received by the lender. Contra, Bank of Utica v. Wager, 2 Cow. 712, 763 (N.Y. 1824). The only dissent in all of these cases was in Planters Bank v. Snodgrass, 5 Miss. (4 How.) 573, 631 (1840). The opinion restated the New York view that intentional taking of excess interest, as opposed to interest taken by accident or mistaken computation, is sufficient evidence of intent to violate the usury law. The opinion noted that this case was the first to involve a loan for longer than one year, which undermines the convenience rationale for the part of the loan that covers a full year.

11 Cf. Planters Bank v. Snodgrass, 5 Miss. (4 How.) 573, 631 (1840).

12334 F. Supp. 888 (D. Ore. 1971).

13 Id. at 889. 
the court held that the lender had violated the statute by knowingly charging interest that effectively exceeded the statutory maximum.4

\section{B. Arguments from Legislative Intent}

By the turn of the century the courts, perhaps prompted by the diminishing validity of the convenience rationale, had ceased to rely exclusively on the specific intent analysis. ${ }^{45}$ They looked, in addition, to justifications based on supposed legislative intent. One court, ${ }^{46}$ perhaps wary of upsetting established bank practice, avoided the clash between the 365/360 method and the state usury statute by finding that the legislature had implicitly approved of the method by enacting the statute without stating any required method of calculation at a time when the $365 / 360$ method was in general use. ${ }^{47}$ This technique of statutory construction is deficient in this context since the court had no evidence that the legislature was aware of the mechanics of the $365 / 360$ method or of its results. The court thought it improbable that the legislature intended to disturb bank practices of that day, but failed to establish from the legislative history that the legislature had considered the question or would have approved of the practice if it had.

Courts disposed to protect borrowers rather than lenders have found equally ingenious techniques for establishing legislative intent. In Dowler v. Georgia Enterprises ${ }^{48}$ the court held that a general construction statute providing that a year is deemed to be a calendar year in the interpretation of other statutes prohibited the use of the $365 / 360$

$44 I d$. at 890 . The parties had stipulated the lender's knowledge that the $365 / 360$ method resulted in more interest than calculation based on exact simple interest. Judge Goodwin also places some weight in the fact that the bank's depositors were paid by exact simple interest; he asserts that this fact makes it clear that the bank was aware of the difference between the alternative methods of calculation. At the time of the decision, it was not clear whether the Federal Deposit Insurance Corporation allowed banks to pay interest calculated on the $365 / 360$ basis. 12 C.F.R. $\$ 226$ (1972). These regulations have since been amended to authorize such calculation specifically. 37 Fed. Reg. 10341 (1972).

45 Despite this tendency, some courts still relied on this reasoning of the older cases. Patton v. Bank of La Fayette, $124 \mathrm{Ga} .965$ (1906); Dickey v. Bank of Clarksdale, 183 Miss. 748, 184 So. 314 (1938); Cox v. Tímlake, 169 Miss. 568, 153 So. 794 (1934).

46 Merchants' \& Planters' Bank v. Sarratt, 77 S.C. 141, 57 S.E. 621 (1907).

47 The court said that "at the time of the adoption of the usury statute [the $365 / 360$ method] was so generally understood and employed by all classes of people in matters of business, was so generally taught in the schools of the state from standard works on arithmetic as the principal method of calculating interest, that it is not at all probable that the Legislature intended to overthrow or interfere with such method." Id. at 143, 57 S.E. at 622.

18 162 Tenn. 59, 34 S.TV.2d 445 (1930). 
method. ${ }^{49}$ The court said that "the adoption of any custom that would shorten the calendar year and correspondingly increase the rate of interest beyond six percent for the calendar year could not be sustained." 50 The analysis in Dowler is afflicted with the same deficiency that besets the implicit approval theory: there is no evidence that the general construction statute was intended to apply so literally to methods of interest calculation. ${ }^{51}$ The legislative history does not reveal that the legislature intended to affect the choice of method of interest computation by passage of this broad statute. ${ }^{52}$ The theory adopted in Dowler is merely an attempt to justify the result reached in American Timber and Ely through the use of weak legislative support rather than reasoned analysis.

\section{The Problem of Remedies}

The courts' reluctance to hold that interest resulting from the application of the $365 / 360$ method to the maximum permissible interest rate is usurious can be understood only in light of the severe remedies imposed by the state usury statutes. The penalty for usury is, in most states, forfeiture by the lender of at least the interest on the debt; in some states, the penalty is invalidation of the loan agreement resulting in forfeiture of interest and principal. ${ }^{53}$ Courts may well believe that it would be excessively harsh to invalidate millions of dollars of loans when the lenders are merely following a trade custom that has received wide judicial acceptance. In addition, considerable inequity would

49 An identical statute is presently in force. TENN. Code ANN. § 1-305(28) (1955).

50162 Tenn. at 64, 34 S.W.2d at 447. If this reasoning is sound, it could be applied in many states. A total of thirty-one states have statutes providing that, in construing other statutes, a year is deemed to be a calendar year. See, e.g., GAL. Gov't CODE $\S 6803$ (1966); Mass. Gen. Laws. ANn. ch. 4, § 7 (1966); Mo. Rev. Stat. § 1.020 (1959); Tex. Rev. Crv. STAT. art. 23(16) (1948).

51 In fact, three states provide that a year is deemed to be a calendar year for calculating interest. See Ill. Rev. Stat. ch. 74, § 10 (1972); LA. Crv. Code ANN. art. 2060 (West 1952); N.Y. GEN. CONSTR. LAW \& 58 (McKinney 1951). Illinois also has a general provision like those referred to above. InL. REv. STAT. ch. 131, § 1.10 (1972).

52 Further, no other court has so applied this statute, although some have had the opportunity. The theory was considered and rejected in Mississippi. Dickey v. Bank of Clarksdale, 183 Miss. 748, 767, 184 So. 314, 318 (1938). (Ethridge, J., dissenting). Although New Jersey has a statute substantially identical to the Tennessee statute construed in Dowler, the issue was not considered in Ditmars v. Camden Trust Co., 10 N.J. 471, 92 A.2d 12 (1952). N.J. REv. STAT. \& 1:1-2 (1963).

53 This penalty is provided in seven states: ARR. STAT. ANN. \$ 68-608 (1947); ConN. Gen. Stat. ANN. § 37-8 (1958); ME. Rev. Stat. ANN. tit. 9, \& 229 (1964) (personal loans over \$2000); Mass. Gen. LAws ANN. ch. 271, § 49(c) (1968); N.Y. GEN. Obligations LAw § 5-511 (McKinney 1964); Miss. CoDE ANN. § 36 (1942) (interest rates over twenty percent); R.I. GEN. LAWS ANN. \& 6-26-4 (1956). The remedy in other states is typically forfeiture of interest or some multiple thereof. 
result from a retroactive change in the legal status of practices that have formed the basis of bargains between borrowers and lenders. ${ }^{54}$

The courts can avoid this inequity and, at the same time, reach the correct result as to the legality of the $365 / 360$ method by making their decisions prospective only. ${ }^{55}$ Shortly after the decision in Ely, a Vermont court applied an effectively prospective remedy to the usury problem..$^{56}$ In Bank of Burlington v. Durkee, ${ }^{57}$ the court used the specific intent analysis to absolve the lender of a charge of usury, but required a refund of all interest above the statutory maximum. ${ }^{58}$ In a companion case, ${ }^{59}$ the same court cautioned that the Durkee decision should be a guide for future contracts and implied that the usury penalty would be applied if the banks did not cease the practice. The New Jersey Supreme Court has since followed this reasoning in Ditmars $v$. Camden Trust Co.; ${ }^{60}$ it failed, however, to make any declaration regarding future action. Without the threat of penalties the practices of lenders will not be affected, since occasional restitution cannot deter a generally profitable practice. Lenders would be able to continue to violate usury statutes with profit, and would merely rebate the excess

54 It has been suggested that "changes in settled law . . . frequently should be limited to prospective operation." $1 \mathrm{~K}$. Davis, Administrative Law Treatise $\S 5.09$, at 352 (2d ed. 1958).

55 It is clear that the courts have the power to so limit their decisions. Great Northern Ry. v. Sunburst Oil \& Ref. Co., 287 U.S. 358, 364 (1932); cf. James v. United States, 366 U.S. 213 (1961), in which the Court overruled Commissioner v. Wilcox, 327 U.S. 404 (1946), on which the defendant in a tax evasion case had relied. The Court acquitted the defendant because "the element of willfulness could not be proven .... so long as the statute contained the gloss placed upon it by Wilcox at the time the alleged crime was committed." 366 U.S. at 221-22. See generally Levy, Realist Jurisprudence and Prospective Overruling, 109 U. PA. L. REv. 1 (1960).

66 In an earlier case, another court had reached a similar result but for different reasons. In State Bank v. Hunter, 12 N.C. 100 (1826), though the judge instructed the jury that the practice was usurious, a verdict was returned for the lender. The judge entered judgment for the lender, however, only after the excess was remitted.

57 1 vt. 399 (1829).

58 The court held that "[a] man must not sustain such a loss as the forfeiture of his whole note ... because he takes or includes too much by mere mistake. . . . The proper remedy for such an evil is, to deduct the excess, and let the just amount be recovered." Id. at 402 .

ธ9 Bank of St. Albans v. Stearns, 1 Vt. 430 (1829). See also Bank of St. Albans v. Scott, 1 Vt. 426 (1829).

6010 N.J. 471, 92 A.2d 12 (1952). The court said that "where ... the illegal interest is received by mistake or a miscalculation made in good faith, and not by intent to evade the usury laws, the transaction itself is not usurious and forfeiture of legal interest does not follow although the illegal interest received must be repaid." 10 N.J. at 498 . Technically, the language regarding return of excess is dictum; the lender had previously agreed to return that amount and the issue in the case was the right of the borrower to recover all interest under the usury statute. However, there is no doubt that this court would require this remittance in future cases. 
interest when the borrowers were successful in court. In addition, borrowers' suits might be rare since the costs of suit may well exceed an individual borrower's loss. These deficiencies in the remedy are evidenced by the fact that, after Ditmars, lenders in New Jersey have continued to use the $365 / 360$ method. $^{\text {it }}$

The restitution provided in Durkee and Ditmars, accompanied by a strong admonition that the full usury penalties will be applied in the future, may be an effective resolution of the problem. ${ }^{62}$ The extraction of illegal interest from the borrower in the particular case would be rectified, but the invalidation of thousands of loan agreements consummated during a period of judicial acceptance of ordinary simple interest would be avoided. At the same time, the threat of future sanctions would stimulate abandonment of the objectionable practices.

\section{The Contractual Interpretation Issue}

Only one reported case has dealt with the contractual problems created by use of the $365 / 360$ method. In Silverstein v. Shadow Lawn Savings \& Loan Association ${ }^{63}$ the court read the term "per annum" literally and stated that where "the instrument sets forth nothing more than that the debt shall bear interest at a specified rate . . the intention of the parties must legally be taken to be that interest shall be computed only by either the $365 / 365$ or the $360 / 360$ method." 64 The issue of contractual interpretation raised in Silverstein involves considerations wholly different from those involved in the usury issue. The question is whether the long-standing use of the $365 / 360$ method gives lenders the right to employ this method where the contract is silent as to method of calculation.

61 After this case was decided, the legislature passed a statute allowing use of the $365 / 360$ method for periods of less than one year. N.J. Rev. STAT. § 31:1-1(d) (Supp. 1972). However, lenders continued to use ordinary simple interest for longer maturities. See Silverstein v. Shadow Lawn Sav. \& Loan Ass'n, 51 N.J. 30, 237 A.2d 474 (1968).

62 The same effect can be attained by holding that the transaction under consideration is not usurious but that in future cases the usury penalty will be applied. This method of decision, however, is less desirable as it does not enforce the usury statute for the benefit of the borrower claiming usury in that case.

6351 N.J. 30, 237 A.2d 474 (1968). Silverstein gave a mortgage to the defendant that was to be repaid over 25 years by equal monthly payments allocated to interest first and then to principal. The amount of the payments was based on calculating interest by the $360 / 360$ method. The lender later shifted to calculating interest by the $365 / 360$ method; the result of this shift was that interest would absorb more of each monthly payment than originally contemplated and that the principal would not be repaid within twentyfive years. This constituted a violation of state law. N.J. Rev. STAT. § 17:12A-78 (Supp. 1955). The court held this shift to be a unilateral fixing of a higher rate of interest than that stated in the agreement; the borrower was allowed to recover the excess based on breach of contract.

6451 N.J. at 43,237 A.2d at 481. 
Established usage ${ }^{65}$ may be used as an aid in construing most agreements. ${ }^{66}$ Reading commercial usage into a contract may, however, create inequities in some contexts since there is a critical difference between consumers and commercial borrowers. Although a party to a contract may, in most cases, be charged with notice of a trade custom despite lack of actual knowledge, ${ }^{67}$ it is difficult to read banking custom into loan agreements with consumers, at least in the absence of some evidence that the borrower could have been aware of customary methods of interest calculation. Most consumers or one-time borrowers have little opportunity to gain knowledge of banking customs and, since their loans are relatively small, little financial interest in doing so. Conversely, commercial or frequent borrowers have a greater interest in bank practices and are probably more aware of methods of computation of interest. Actual knowledge of the customary use of the $365 / 360$ method should, however, be binding on all borrowers since they would expect the custom to apply absent agreement to the contrary. ${ }^{68}$ Two major issues are presented by these contractual disputes over the use of the $365 / 360$ method-whether any custom or usage exists and whether such custom or usage should be applied in construing a particular contract. ${ }^{69}$

When use of the $365 / 360$ method is widespread, commercial borrowers should, absent agreement to the contrary, be held to have intended its application despite lack of actual knowledge. Unless adequate disclosure is made by lenders, however, consumer and one-

65 The term "usage" is defined as a method of doing business that is generally observed in a trade. Cf. United States v. Stanolind Crude Oil Purch. Co., 113 F.2d 194, 200 (10th Cir. 1940); UNIForm CoMmerciar CoDE § 1-205(2).

60 Commercial Ins. Co. v. Hartwell Excavating Co., 89 Idaho 531, 541, 407 P.2d 312, 317 (1965); cf. Reely v. Chapman, 177 Cal. App. 2d 260, 262, 2 Cal. Rptr. 188 (1960); Redding v. Snyder, 352 Mich. 241, 246, 89 N.W.2d 471, 474 (1958).

67 Johnson Bros. Boat Works v. Conrad, 58 N.J. Super. 334, 156 A.2d 175 (1959); Kerr v. Taylor, 317 S.W.2d 589 (Tex. 1958). Contra, Wise v, Reeve Electronics, Inc., 183 Cal. App. 2d 4, 6 Cal. Rptr. 587 (1960).

68 Wise v. Reeve Electronics, Inc., 183 Cal. App. 2d 4, 6 Cal. Rptr. 587 (1960); Commercial Ins. Co. v. Hartwell Excavating Co., 89 Idaho 531, 407 P.2d 312 (1965). Of course, this analysis assumes the absence of any statutory authority that could not be altered by custom or usage. See text at note 19 supra \& note 51 supra. "Although customs and usages of the banking business may have a binding force as between banks, and between a bank and the person with whom it deals in the absence of an express agreement to the contrary, the custom or usage must not be repugnant to the express provisions of a statute." Cooke v. Commercial Bank, 119 So. 2d 732 (Fla. 1960).

69 In Silverstein the lender had trouble passing the first of these hurdles; the assertion of usage was contested by the New Jersey Commissioner of Banking, the New Jersey Bankers Association, and the Savings Bank Association of New Jersey who appeared as amici curiae to state that the overwhelming practice in the state was to use exact simple interest. It may be that New Jersey is the exception rather than the rule in this regard. See text and notes at notes 5-7 supra. 
time borrowers will probably assume that percentage per annum means what it says and will be accurately computed; ${ }^{70}$ thus, absent actual knowledge, these borrowers should not be bound by the custom. ${ }^{71}$

\section{CoNCLUSION}

Different considerations are presented when use of the $365 / 360$ method pushes the effective rate of interest over the lawful limit.

70 There are many situations in which the proposition that 12 percent means twelve dollars per one hundred dollars per 365 days does not hold. Taking interest in advance is the primary example. Where a note is discounted at 12 percent for 365 days the annual rate of return to the lender is 13.6 percent; yet this method of collecting interest has received approval as a custom of the banking industry. See cases cited note 33 supra. Other examples involve increased yield to depositors such as daily compounding and paying interest on money deposited by the tenth of a month from the first, each of which has a greater effect on the nominal rate than calculation by the $365 / 360$ basis. FDIC has recently amended its rules to allow banks to pay interest on deposits by the $365 / 360$ method. 87 Fed. Reg. 10341 (1972). In fact, M. MEYer \& J. McDaniel, Don'T Bank ON ITl (1970) describes methods by which savers can take advantage of these "inaccuracies" and substantially increase the interest rate paid on savings.

The practice is not limited to the banking industry and is widely used in commercial dealings. In the garment industry, buyers of piece goods are allowed "anticipation" for payments made within sixty days. This discount is computed on the $365 / 360$ basis. The practice of the Treasury Department is to publish annual interest rates for Treasury bills based on the $365 / 360$ method of calculation. The Treasury refers to this method as "bank discount basis." In footnotes the Treasury also indicates rates based on a "true discount" using the 365/365 method. The Treasury clearly distinguishes between the two methods. Bankers Association Brief, supra note 6, at 24. The New York Stock Exchange, in calculating accrued interest on listed bonds, also uses the $365 / 360$ method. 2 CCF N.Y. STOCK Exch. GUIDE II $2241-42$.

Admittedly, these examples are all cases in which the $365 / 360$ method is contracted for and understood due to public notice. Thus, the real question regarding the use of ordinary simple interest is whether the usage is so well known as to render express agreement unnecessary.

71 Once the distinction between consumer and commercial borrowers is made in the contractual interpretation cases, the propriety of maintaining a class action is called into question. Although there may be common questions, the presence of issues concerning frequency of bank dealing and constructive or actual knowledge may frustrate the commonality of the purported class. Thus, unless the substantive requirements of recovery are altered for class actions, it would seem difficult to justify the maintenance of class suits here. See generally Comment, The Impact of Class Actions on Rule 10b-5, $38 \mathrm{U}$. CHI. L. REv. 337 (1971). In Silverstein, the court rejected a class action claim for another reason: "[T] his defendant is subject to the supervisory and regulatory power of the Commissioner [of Banking and Insurance] and we feel certain that a class judgment is not required to assure that he will see to it that our conclusion is fully implemented for the benefit of all entitled mortgagors." 51 N.J. at 45, 237 A.2d at 482. Thus, rather than simplify the judicial process, the class action mechanism would unduly hamper the courts. The court did, however, treat the action as a class action for the purpose of assessing attorney's fees.

The issue of commonality is more in favor of class actions on the usury question. No court has considered the question as yet. In American Timber the court postponed a consideration of the propriety of a class action until after resolution of the substantive issue. There are no significant individual issues on this question; the only question to be resolved is whether the usury statute is applicable to a particular transaction. 
To exonerate the lender completely loses sight of the protective purpose of usury legislation, while to hold the practice usurious is unfair to lenders, given its long judicial acceptance. It is possible for the courts to effect an adequate solution by holding that the practice shall be treated as usurious in the future while limiting damages for past violations to the amount of the excess interest.

The problem underlying both the usury and contract issues is truth in lending, but the federal and state statutes do not address the particular difficulties created by the use of the 365/360 method. Under the federal act ${ }^{72}$ and Regulation $Z^{73}$ the disclosure rules do not apply to commercial loans or large consumer loans, ${ }^{74}$ which represent a significant amount of outstanding indebtedness nationally. As discussed above, the problem is more acute for consumer borrowers; for these loans disclosure of the actual dollar amount of interest ${ }^{75}$ and the annual interest rate calculated over 365 days $^{76}$ are required. These protections, however, are not totally effective. Borrowers are protected only to the extent that they will know the interest rate and dollar cost in advance. The borrower may not notice the difference in dollar amount between exact simple interest and ordinary simple interest without complicated calculations since no comparison standard is provided. In addition, the annual percentage rate may be rounded off for purposes of the truth-in-lending statement to the nearest one-fourth of 1 percent. ${ }^{77}$ This rounding off conceals the effect of the computation method for periods of one year where the nominal rate is less than 9 percent. The Congress and Federal Reserve Board have decided not to take any ameliorative action. ${ }^{78}$ The most effective solution would undoubtedly be a legislative requirement of full disclosure of the method of interest calculation and the precise actual yield over 365 days.

\section{Richard J. Bronstein}

7215 U.S.C. $\$ \S 1601-65$ (1970).

7312 G.F.R. § 226 (1972).

7415 U.S.C. $\S 1603$ (1970); 12 C.F.R. § 226.3 (1972). Apparently the assumption is that businessmen can take care of themselves. One of the pending suits, however, was instigated by an attorney dealing with a bank both on his own behalf and as agent for various corporations. Perlman v. First Nat'l Bank, $70 \mathrm{CH} 3653$ (Cook Cty. Cir. Ct., filed Aug. 3, 1970).

7515 U.S.C. \& 1639 (1970); 12 C.F.R. \& 226.8 (1972).

76 Federal Reserve Board Letter, Nov. 24, 1969, reproduced in 4 CCH Consumer Credit Guide $\mid$ i 30,214 .

77 I5 U.S.C. \& 1606(c) (1970); 12 C.F.R. \$ 226.5(b) (1972).

78 Cf. 4 CCH Consumer Credit GuIde If 99,359. But see 118 Cong. Rec. H 6847 (daily ed. July 24, 1972). 